\title{
MASA DEPAN KAJIAN ISLAM DI INDONESIA*
}

\author{
Ismail Suardi Wekke ${ }^{* *}$ \\ Sekolah Tinggi Agama Islam Negeri (STAIN) Sorong \\ email: iswekke@gmail.com
}

\begin{abstract}
Islamic higher educations in Indonesia extend their roles in many ways. They perform institutional organization to wide capacity and educational activities. First bacth, there were six universities to transform. After the first batch, there were a huge numbers of transformations either from college to institute or institute to university. Unfortunately, best practices from first batch did not apply to the next cohort. This paper discusses three main area, they are current condition, achievement, and opportunities to explore. On the other hand, regional situation in Southeast Asia is not the only one to overlook. There is the environment surrounding our higher education in providing service to community. Finally, this recent problems need to extend in the world condition of higher education.
\end{abstract}

Keywords: Higher Education, Islamic Higher Education, Islam and Higher Education

\section{PENDAHULUAN}

Era transformasi awal perguruan tinggi Islam dengan enam institusi Universitas Islam Negeri di enam kota yaitu Pekanbaru, Jakarta, Bandung, Yogyakarta, Malang, dan Makassar sementara menapaki sepuluh tahun kedua. Dalam satu dasawarsa ini, maka enam perguruan tinggi tersebut sudah mulai menemukan bentuk kelembagaan yang mapan. Bahkan membentuk dua fakultas baru yaitu Fakultas Ekonomi dan Bisnis Islam, dan Fakultas Kedokteran dan Ilmu Kesehatan. Dengan demikian, sudah saatnya untuk menempatkan secara terintegrasi distingi kelembagaan semua perguruan tinggi Islam dalam tiga strata yang ada saat ini di sekolah tinggi, institut, dan universitas.

Tahap pertama berupa transformasi kelembagaan sudah selesai. Hanya saja, tidak seperti enam lembaga di tahap awal yang mengiringinya juga dengan landasan pengembangan keilmuan yang dimulai dengan pendekatan filsafat keilmuan. ${ }^{1}$ Lembaga-lembaga setelahnya tidak menjadikan proses dialektika keilmuan sebagai tahapan untuk memulai proses tranformasi. Termasuk STAIN yang bertranformasi ke IAIN, sejatinya memerlukan juga penetapan model keilmuan yang dikembangkan untuk menjadi acuan bersama. Walaupun tersedia, terkadang proses wacana keilmuan tidak dimulai

* Disampaikan pertama kali dalam forum International Student Conference on Islamic Studies, Institut Agama Islam Negeri (IAIN) Manado, selanjutnya disempurnakan dalam beberapa kesempatan. Terakhir, seusai Focus Group Discussion juga di Institut Agama Islam Negeri (IAIN) Manado, 28-30 Desember 2017.

** Dosen di Sekolah Tinggi Agama Islam Negeri (STAIN) Sorong, turut menjadi pemrakarsa pembentukan Southeast Asia Academic Mobility (SEAAM) yang berlangsung dalam rangkaian International Postgraduate Research Conference (IPRC) 2016. Menjabat sebagai Wakil Ketua Umum Majelis Sinergi Kalam Ikatan Cendekiawan Muslim SeIndonesia, 2015-2020.

1 M. Amin Abdullah mengistilahkan dengan integrasi sains-Islam. Amin Abdullah, Integrasi Sains-Islam: Mempertemukan Epistemologi Islam dan Sains. Yogyakarta: Pilar Religia, 2004. 
dari sisi tersebut. Tantangan lainnya, tersedia proses diskursus keilmuan tetapi tidak dipublikasikan. Sehingga diseminasi informasi tidak terlaksana.

Sementara itu, tidak saja di kota-kota besar tetapi juga mencapai kawasan di Timur Indonesia. Sekolah Tinggi Agama Islam Negeri Alfatah Jayapura dan Sekolah Tinggi Agama Islam Negeri Sorong bertempat di Tanah Papua. Keduanya menjadi pilar dakwah, akademik, dan kebangsaan. Terakhir, Provinsi Sulawesi Barat menempatkannya di Kabupaten Majene, justru bukan di ibukota provinsi, Sekolah Tinggi Agama Islam Negeri Majene. Termasuk perluasan mandat untuk mengelola program studi yang diintegrasikan dengan kurikulum keagamaan yang menjadi koordinasi Kementerian Riset, Teknologi, dan Pendidikan Tinggi.

Perkembangan dalam sepuluh tahun terakhir inilah yang menjadi landasan untuk mencipta peluang di sepuluh tahun berikutnya. Jikalau pada beberapa kesempatan sudah dilakukan penguatan pada aspek keberagamaan, maka aspek ini perlu diintegrasikan dengan instrumen yang lain sehingga dapat menjangkau masyarakat lebih luas. ${ }^{2}$ Hanya saja jika tidak dijadikan sebagai pijakan strategik sekarang ini, maka momentum yang sudah ada sebelumnya akan segera menghilang. Dengan demikian, saatnya untuk mengemukakan beberapa hal berkaitan dengan aspek pengembangan dan tantangan yang dihadapi seiring dengan semakin menguatnya keperluan akan teknologi informasi.

Perguruan tinggi Islam menjadi kajian tersendiri dimana dalam aspek transformasi diiringi pula dengan tranformasi keilmuan, jika awalnya hanya dalam mono-disiplin, perguruan tinggi juga melengkapi transformasi kelembagaan dengan tranformasi keilmuan menjadi inter-disiplin atau trans-disiplin. ${ }^{3}$ Fokus pembelajaran tetap perlu diperhatikan sebagai pilar utama pembelajaran, ${ }^{4}$ namun perkembangan terkini dalam bidang pendidikan tinggi juga perlu mendapat perhatian.

\section{CAPAIAN PERGURUAN TINGGI ISLAM}

Dalam beberapa kesempatan Jusuf Kalla menyatakan bahwa jikalau belajar Islam, maka Indonesia dapat saja menjadi acuan. Bukan saja Mesir, dan negara-negara di Timur Tengah lainnya. Bahkan, Indonesia sangat layak dalam konteks Asia Tenggara. ${ }^{5}$ Dari 57 institusi sudah tersedia empat jurnal bereputasi internasional, tercatat dalam pangkalan data Scopus, berturut-turut Universitas Islam Negeri Sunan Kalijaga, Aljamiah; Universitas Islam Negeri Syarif Hidayatullah, Studia

${ }^{2}$ Ismail Suardi Wekke, Asep Hermawanto, dan Muhammad Ashrori, "Keberagamaan Mahasiswa di Perguruan Tinggi Wilayah Minoritas Muslim." ULUL ALBAB Jurnal Studi Islam, Volume 17, No. 2, (2017), h, 135-146.

3 Universitas Islam Negeri Maulana Malik Ibrahim Malang secara berkala menerbitkan buku untuk tahapantahapan tranformasi. Quo Vadis Pendidikan Islam, Malang: UIN-Malang Press, 2006 dengan editor Mudjia Rahardjo salah karya tersebut, terdapat 22 tulisan yang menjadi kumpulan tulisan para pakar dalam menyoroti proses keilmuan di UIN Malang yang berawal dari Fakultas Tarbiyah IAIN Sunan Ampel.

4 Mantz Yorke. "Formative assessment in higher education: Moves towards theory and the enhancement of pedagogic practice." Higher Education, Volume 45, Number 4, (2003), pp. 477-501.

5 http://www.tribunnews.com/nasional/2016/12/14/jusuf-kalla-saatnya-asean-menjadi-pusat-ajaran-islamdunia,https://www.merdeka.com/peristiwa/wapres-jk-islam-indonesia-islam-moderat.html, https:// nasional.tempo.co/read/1028837/jusuf-kalla-indonesia-bisa-jadi-contoh-negara-toleran-di-dunia, http://nasional.republika.co.id/berita/nasional/umum/17/04/23/oov89w354-wapres-jk-islam-di-indonesia-islammoderat, juga dalam kesempatan ketika menyampaikan kuliah tamu di Oxford University, Inggris Raya http://internasional.kompas.com/read/2017/05/19/22052331/ini.kata.jusuf.kalla.di.oxford.soal.islam.indonesia.dan.vo nis.ahok. 
Islamika; Universitas Islam Negeri Sunan Ampel, Journal of Indonesian Islam; Institut Agama Islam Negeri Salatiga, Indonesian Journal of Islam and Muslim Societies.

Sementara capaian secara nasional, terakhir ini di Universitas Islam Negeri Syarif Hidayatullah, enam jurnal terakreditasi. ${ }^{6}$ Untuk kajian secara khusus, ada empat jurnal terakreditasi yang fokus pada kajian gender: Musawa, Universitas Islam Negeri Sunan Kalijaga; Palastern, Sekolah Tinggi Agama Islam Negeri Kudus; Kafaah, Universitas Islam Negeri Imam Bonjol; dan Sawwa, Universitas Islam Negeri Walisongo. Dengan kondisi seperti ini menunjukkan bahwa dalam pengembangan kajian Islam sudah didasarkan pada kajian keislaman melalui kecenderungan masyarakat ilmiah antarbangsa. Kajian gender tidak lagi hanya didekati dengan kajian teks semata tetapi sampai pada publikasi hasil-hasil riset dengan instrumen jurnal.

Dalam soal reputasi akreditasi, Universitas Islam Negeri Sunan Kalijaga dan Universitas Islam Negeri Syarif Hidayatulah secara bersama-sama sudah melakukan akreditasi regional seperti ASEAN University Network Quality Assurance (AUN-QA). Dengan akreditasi AUN-QA, maka lulusan perguruan tinggi tersebut memiliki kesempatan secara luas di seluruh kawasan Asia Tenggara baik untuk bekerja ataupun membangun karir sesuai pilihan lahan pengabdian. Sebelumnya, tiga perguruan tinggi sudah mencapai akreditasi institusi tertinggi, A. Yogyakarta, Jakarta, dan Malang, ketiganya bisa bersanding dengan perguruan tinggi lainnya yang tidak lebih dari dua puluh perguruan tinggi di kelompok awal akreditasi perguruan tinggi. Kalau sekarang, sebaran akreditasi perguruan tinggi dengan nilai A, mulai juga dicapai pelbagai perguruan tinggi tidak hanya di Pulau Jawa saja tetapi juga sampai ke utara Sulawesi.

Dari enam universitas di fase awal tiga diantaranya sudah mengelola fakultas kedokteran, Jakarta, Malang, dan Makassar. Rumah sakit pendidikan juga sudah dilengkapi. Dengan demikian, perguruan tinggi Islam tidak lagi sekadar untuk menjadi juru dakwah saja secara formal tetapi menjadi da'i dalam arti yang luas. ${ }^{7}$ Jikalau seorang dokter lulusan dari universitas Islam tentu memiliki bekal dalam praktiknya untuk mengintegrasikan nilai Ilahiyah dalam menjalankan profesi kedokteran. Ini tentu tidak lagi sekadar menjadikan sandaran pada rasionalitas dan empirisme saja, tetapi wahyu memandu proses medis.

Dalam aspek jenjang pendidikan, walaupun Sekolah Tinggi Agama Islam Negeri Alfatah Jayapura dan Sekolah Tinggi Agama Islam Negeri Sorong merupakan dua lembaga yang berada di paling timur, namun keduanya sudah mengelola pendidikan magister. Ini sebuah kesempatan untuk menyediakan akses pendidikan ke jenjang yang lebih tinggi. Termasuk pula, Universitas Muhammadiyah Parepare dan Universitas Muhammadiyah Makassar yang juga sudah mengelola pendidikan doktoral.

Sementara itu, peran regional untuk kawasan Asia Tenggara mulai diakselerasi. Sejak 2010, perguruan tinggi Islam melaksanakan paling dua program secara berkesinambungan, dimulai dari pemberian beasiswa kepada mahasiswa yang berasal dari Thailand, Cambodia, dan Vietnam. Mereka tersebar di perguruan tinggi dengan status mahasiswa penuh waktu. Begitu pula dengan pengiriman

${ }^{6}$ Surat Keputusan Direktur Jenderal Penguatan Riset dan Pengembangan Kementerian Riset, Teknologi, dan Pendidikan Tinggi Nomor 48a/E/KPT/2017, tanggal 30 Oktober 2017.

${ }^{7}$ Ismail Suardi Wekke. "Lembaga Pendidikan Sebagai Pilar Dakwah di Wilayah Minoritas Muslim." Jurnal Dakwah Alhikemah, Volume 4, No. 2, (2013), h. 93-118. 
mahasiswa untuk melaksanakan praktikum di sekolah-sekolah Thailand selama satu semester. Dengan interaksi seperti ini, perguruan tinggi Islam Indonesia menjadi sarana untuk memberikan kesempatan kepada masyarakat Muslim Thailand dalam mengakses pendidikan tinggi Islam. Pada saatnya, mereka akan menjadi lulusan dalam kapasitas "duta” Islam Indonesia.

\section{TANTANGAN BAGI KAJIAN ISLAM DI PERGURUAN TINGGI}

Ada peluang yang terbentang luas bagi alumni perguruan tinggi Islam untuk tetap menjadi bagian dari masyarakat di era digital sekarang. Para mahasiswa perlu melengkapi dirinya dengan keterampilan dan penguasaan teknologi informasi. Jikalau seorang alumni program studi Ilmu Alquran dan Tafsir mengembangkan sebuah perangkat lunak untuk menjadi perangkat dakwah, karena ini didukung dengan kapasitas dan kapabilitas keilmuan, maka akan menjadi sebuah sumber belajar yang memadai. Dengan demikian, sebuah kesempatan bagi setiap alumni perguruan tinggi untuk tetap relevan dengan kebutuhan masyarakat hari ini. Dengan ciri khas masyarakat digital yang memperoleh informasi serba cepat, bahkan instan, dan maklumat yang komprehensif, ini menjadi sebuah peluang untuk melakukan pengembangan dan adaptasi keilmuan dalam kajian Islam yang berhubungan langsung dengan masyarakat.

Sementara ini kita saksikan informasi yang disampaikan Ustadz Abdul Somad bisa menyebar dengan sangat cepat. Semuanya bisa terjadi karena terdistribusi melalui platform digital. Mulai dari media sosial seperti instagram dan facebook, sampai pada layanan video seperti Youtube. Dengan instrumen ini memungkinkan orang-orang yang tidak hadir sekalipun dalam majelis ilmu tersebut secara langsung, dapat saja terhubung untuk menyimak ceramah yang disampaikan. Bahkan setelah itupun juga masih bisa diputar ulang sehingga melintasi batasan ruang dan waktu.

Kalaulah alumni program studi Komunikasi Penyiaran Islam (KPI) di perguruan tinggi keagamaan Islam melakukannya, ini tidak saja pada penyebaran tetapi juga pada content yang kredibel. Untuk itu, alumni perguruan tinggi Islam tetap perlu menjadi pionir dalam dakwah yang semata-mata tidak hanya di mimbar saja. Keuntungan dari dakwah yang didokumentasikan dan dipublikasikan melalui media online, umat dan jamaah bisa mengaksesnya kapan saja dan bisa disesuaikan dengan keperluan saat itu. Panduan-panduan ibadah jikalau saja dapat dibuat dalam bentuk platform digital, maka proses belajar akan memudahkan terutama bagi golongan dewasa.

Selanjutnya adalah tugas para sarjana muslim untuk memerangi hoax. Bukan saja karena kebiasaan untuk melanjutkan informasi tanpa melakukan verifikasi sebelumnya, juga karena tidak tersedianya informasi yang kredibel. Maka, sudah perlu adanya program yang terencana, terstruktur, dan massif untuk menyediakan informasi-informasi yang sahih dan dapat menjadi rujukan masyarakat. Dua warga net diantaranya yang kerap menjadi perbincangan yaitu Jonru dan Abu Janda. Keduanya bahkan tidak memiliki kapasitas keilmuan secara formal. Namun dengan kehadirannya di media sosial kemudian dapat menggiring opini. Bahkan secara khusus, Jonru menggugat keberadaan Quraish Shihab dengan memberinya label Syiah. Padahal, secara keilmuan, Jonru tidaklah memiliki jejak rekam keilmuan Islam. Hanya saja, karena kemampuannya merangkai kata di dunia maya sehingga menjadi kesempatan untuk disebarluaskan. Oleh karenanya, para sarjana muslim perlu dibekali kemampuan untuk menyebarkan informasi yang sudah terverifikasi. 
Peningkatan kapasitas dan percepatan untuk jenjang jabatan fungsional juga menjadi agenda tersendiri. Sejak awal perlu diperhatikan untuk menjadikan publikasi sebagai kebutuhan. Bukan tuntutan untuk kenaikan pangkat semata. Akibatnya, Universitas Islam Negeri Imam Bonjol menghasilkan guru besar terakhir kali pada tahun 2008. Sepanjang kurun waktu sepuluh tahun, belum ada lagi guru besar. Kendala utamanya terletak pada publikasi bereputasi. Untuk itu, publikasi sejatinya menjadi bagian integral dalam pelaksanaan tri dharma perguruan tinggi. Baik pendidikan dan pengajaran, maupun pengabdian masyarakat, dijadikan sebagai dasar untuk melakukan publikasi. Terlebih lagi, dalam riset yang menuntut adanya publikasi.

Tidak hanya dalam kaitan pengembangan akademik semata. Tetapi juga dinamika eksternal perlu disinergikan sehingga perguruan tinggi Islam senantiasa relevan dengan perkembangan masyarakat. Sebuah institusi bisa saja berangsur ditinggalkan jika tidak memenuhi keperluan dan hajat masyarakat. Sehingga perguruan tinggi perlu melakukan inovasi secara berkesinambungan dan memperluas akses. Tidak lagi sebatas di Indonesia saja tetapi juga mulai mempertahankan perluasan jaringan yang sudah dilaksanakan di Asia Tenggara.

\section{MASA DEPAN PERGURUAN TINGGI ISLAM}

Proses kelembagaan bergulir, secara bertahap sekolah tinggi menjadi institut, dan terakhir enam institut menjadi universitas. Dengan demikian, seiring dengan trasnformasi kelembagaan tersebut maka iklim akademik juga perlu dijadikan sebagai tumpuan. Tidak lagi hanya menjadi perguruan tinggi Islam sebagai lembaga dakwah melainkan menjadikan pondasi ilmu pengetahuan sebagai sarana dalam beragama. Dengan demikian, masyarakat muslim Indonesia juga menyandarkan diri pada keberagamaan yang didasari pada nalar pengetahuan untuk memahami terminologi keislaman.

Selanjutnya, program studi yang bersentuhan dengan seni perlu mulai merambah pada kontekstualisasi seni sebagai sarana dakwah. Kesemarakan media popular seperti film bioskop dan film pendek perlu dijadikan sebagai perhatian. Penyebaran informasi secara populer akan memudahkan berbanding dengan transfer informasi secara kaku dan dalam bentuk pendidikan formal. Maka, perlu didiskusikan bahwa tugas akhir mahasiswa tidak lagi sekadar pada skripsi semata. Sementara program studi yang menetapkan capaian pembelajaran yang berkaitan dengan komunikasi perlu melengkapi dengan tugas yang berwujud karya seni. Bahkan jikalau program studi yang mensyaratkan penulisan skripsi, tidak lagi sekadar hanya sebatas skripsi saja tetapi perlu dilanjutkan menjadi artikel jurnal. Selama ini, skripsi, tesis, dan disertasi hanya dibaca oleh pembimbing dan penguji saja. Padahal, dengan temuan-temuan yang dihasilkan dapat saja menjadi bahan dalam pengambilan keputusan untuk pengambilan kebijakan.

Platform penerbitannya-pun tidak lagi menjadi masalah. Repository gratis sudah tersedia seperti Research Gate, Academia, INARxiv, bahkan perguruan tinggi masing-masing sudah membangun repository secara mandiri juga. Perguruan tinggi Islam juga sudah menempatkan repositorinya dalam peringkat global bersama dengan perguruan tinggi lainnya di Asia Tenggara. Tenaga terampil-lah yang menjadi kuncniya. Kepala perpustakaan ditempati lulusan program studi perpustakaan dari perguruan tinggi terkemuka, bahkan dengan status pustakawan mereka mencapai pendidikan sampai jenjang doktor. Dimana syarat doktor bukan sebuah keharusan. 
Sekarang ini, Kementerian Agama RI tidak hanya membenahi infrastruktur dengan dukungan pendanaan yang berasal dari sumber-sumber alternatif tetapi juga mengantisipasi kebutuhan sumber daya manusia. Program 5000 doktor menargetkan untuk penyelesaian pendidikan strata tiga bagi dosen-dosen baik dalam negeri maupun luar negeri sebanyak 5.000 orang. Ini akan menyediakan tenaga dosen tidak lagi didominasi oleh lulusan pendidikan magister tetapi sudah mencapai derajat tertinggi dalam jenjang pendidikan formal.

Sementara itu, keberadaan kepemimpinan perempuan diterima sebagai bagian dari civitas akademika. Bukan hanya sebagai dosen tetapi menjadi pimpinan perguruan tinggi. Diantara perguruan tinggi tersebut IAIN Manado yang dipimpin Dr. Hj. Rukmina Gonibala, IAIN Metro dengan nahkoda Prof. Dr. Hj. Enizar, dan IAIN Ponorogo dengan rektor Dr. Hj. Maryam Yusuf. Sementara di tingkat wakil rektor, bukan saja wakil rektor dengan tugas yang sederhana seperti bidang akademik atau bidang keuangan, dosen-dosen perempuan juga menjabat di wakil rektor bidang kemahasiswaan. Dimana mengurusi mahasiswa yang memiliki dinamika dan intensitas yang kompleks, diantaranya di UIN Alauddin Makassar, Prof. Dr. Aisyah Kara; IAIN Manado, Dr. Evra Wilya; dan IAIN Metro, Dr. Ida Umami.

Sementara itu, pimpinan perguruan tinggi secara rutin menyampaikan sambutan dalam pelbagai acara. Jikalau saja, gagasan dan pokok-pokok pikiran ini diabadikan dalam bentuk dokumen tertulis akan menjadi kesempatan bagi perguruan tinggi dalam mengedukasi masyarakat. Walaupun sambutan tersebut dilaksanakan secara spontan tetapi karena disampaikan dalam forum kampus, maka tetap saja akan menjadi sarana untuk mendapatkan informasi. Sehingga jika 57 pimpinan perguruan tinggi menyampaikan sambutan sekali saja dalam sebulan, maka paling tidak ada 684 naskah sambutan selama setahun. Belum lagi dalam acara wisuda, penyambutan mahasiswa, yudisium alumni, dan pelbagai rutinitas perguruan tinggi lainnya. Jika bersamaan dengan video dan juga naskah pidato, selanjutnya naskah tersebut disatukan dalam sebuah buku edited volume dan ditempatkan di Google Books, dengan mudah akan diakses oleh siapapun juga. Walau tidak memegang naskah cetaknya, pembaca secara leluasa bisa mengakses informasi dalam buku. ${ }^{8}$

Merebaknya kajian gender sebagai bagian dari respon wacana sosial yang berkembang juga menjadi perhatian perguruan tinggi Islam. Setiap perguruan tinggi secara khusus mendirikan Pusat Studi Anak dan Gender, secara terprogram pula mengelola penerbitan ilmiah yang pada saat ini sementara dengan empat jurnal nasional terakreditasi. Sebelum itu tujuh belas tahun sebelumnya, kajian gender bahkan ditulis secara khusus dalam disertasi seperti karya Zaituna Subhan', dan Nasaruddin Umar ${ }^{10}$.

Terdapat relasi antara dua institusi tertua yaitu Yogyakarta dan Jakarta yang merebak ke seentaro negeri. Keberadaan para guru besar yang awalnya menyelesaikan pendidikan baik di Yogyakarta maupun di Jakarta. Sekarang mulai bertambah dengan capaian para alumni pendidikan luar negara yang menyelesaikan pendidikan di MicGill University, Kanada; Leiden University,

\footnotetext{
${ }^{8}$ M. Amin Abdullah secara khusus menuliskan dua buku “Studi Agama Normativitas atan Historisitas?” Yogyakarta: Pustaka Pelajar, 1996 dan “Islamic Studies di Perguruan Tinggi Pendekatan Integratif-Interkonektif” Yogyakarta: Pustaka Pelajar, 2006.

9 Zaitunah Subhan, Tafsir Kebencian, Yogyakarta: LKiS, 1999.

${ }^{10}$ Nasaruddin Umar, Argumen Kesetaraan Jender Perspektif Al-Qur'an, Jakarta: Penerbit Paramadina, 2001.
} 
Belanda; Flinder University, Australia, dll. Interaksi para dosen dengan lembaga pendidikan luar negara menjadikan perguruan tinggi Islam tidak asing dalam wacana global. Bahkan para dosen menyelesaikan pendidikan dengan akses beasiswa yang prestisius seperti Fulbright, Australia Development Scholarship. Dimana hanya akademisi dengan kualifikasi yang memadai yang bisa menerima beasiswa tersebut.

Begitu juga dengan keberadaan khazanah lokal masing-masing bersinergi dengan keberadaan perguruan tinggi keagamaan. Sebagaimana di Ambon, baik IAIN Ambon maupun Sekolah Tinggi Agama Kristen Negeri (STAKPN) Ambon saling bahu membahu dalam pengembangan akademik. Perguruan tinggi keagamaan tidak secara ekslusif hanya berjalan dalam lingkup agama tertentu saja tetapi juga secara terbuka menerima penganut agama lain. Salah satu disertasi yang diselesaikan di UIN Jakarta ditulis Gregorius Soetomo, seorang pastor dengan judul Bahasa, Kekuasaan, dan Sejarah: Historiografi Islam Marshall G. S. Hodgson dalam Perspektif Kajian Poststrukturalisme Michel Foucoult. Pendeta tersebut bersedia dibimbing para cendekiawan muslim, salah satunya karena percaya bahwa keberadaan perguruan tinggi Islam senantiasa terbuka untuk menerima mahasiswa dari pelbagai kalangan.

Hubungan masyarakat Universitas Islam Negeri Alauddin Makassar secara khusus memiliki kanal di Facebook dengan akun resmi terverifikasi. Dengan hadirnya media facebook ini, kesempatan masyarakat untuk mendapatkan pandangan resmi UIN Alauddin lebih terbuka. Maka, sudah menjadi keperluan bagi perguruan tinggi Islam untuk mulai mengelola akun resmi perguruan tinggi. Sehingga para pengguna dunia maya memahami informasi yang tersebar. Trmasuk akan melihat sumber informasi yang menerbitkannya.

Terakhir, perguruan tinggi mulai menyandingkan proses pembelajaran dengan institusi pesantren. Sebagaimana di UIN Malang, setiap mahasiswa wajib untuk mengikuti proses ma'had 'aly selama tahun pertama. Dengan aktivitas pembelajaran bahasa Inggris dan bahasa Arab, kegiatan ini menjadi awal penguatan keterampilan mahasiswa sehingga pada tahun selanjutnya mereka bisa menempuh proses menjadi sarjana muslim dengan penguasaan ilmu alat yang memadai. Sekaligus, mempermudah proses pendidikan akses terhadap sumber-sumber keilmuan yang berbahasa asing. Sementara itu, agenda yang tak kalah pentingnya memastikan adanya kesinambungan antara pendidikan menengah dengan pendidikan tinggi. ${ }^{11}$

\section{PENUTUP}

Perguruan tinggi Islam tidak lagi menjadi pilihan kedua seiring dengan transformasi kelembagaan. Kalangan masyarakat perkotaan mulai menempatkan perguruan tinggi Islam sebagai wadah menempah anak-anak mereka. Dua puluh tahun yang lalu, teramat susah mencari lulusan dari sekolah menengah atas dari kota. Hampir seluruh teman sekelas kami hanya berasal dari kabupatenkabupaten, itu terbatas dari madrasah aliyah saja. Sekarang ini, mahasiswa yang sementara duduk di bangku kuliah sudah mulai menjadikan perguruan tinggi Islam sebagai tempat belajar. Di samping karena keragaman program studi, juga karena fasilitas yang juga memungkinkan untuk melatih keterampilan yang sama saja dengan perguruan tinggi lainnya.

\footnotetext{
${ }^{11}$ Basuki, Arif Rahman Hakim, Edi Irawan, Menakar Integrasi Interkoneksi Keilmuan, Ponorogo: STAIN Ponorogo,
} 2016. 
Inovasi pendidikan dilaksanakan dari waktu ke waktu. Ukuran pencapaian yang digunakan secara global juga menjadi acuan yang sama. Sehingga lulusan perguruan tinggi keagamaan Islam tidak lagi hanya bekerja di Kementerian Agama RI saja, hampir secara menyeluruh semua kementerian menerima lulusan perguruan tinggi Islam. Namun demikian, peluang kerja yang semakin menyempit di kementerian perlu menjadi perhatian tersendiri. Kesempatan untuk menjadi Aparatur Sipil Negara semakin menyempit kalau tidak dinyatakan tertutup, secara khusus tiga tahun pertama kepemimpinan Presiden Joko Widodo menutup pintu seleksi ASN. Maka, saatnya mempersiapkan lulusan perguruan tinggi Islam untuk memiliki kiprah yang luas sesuai dengan dinamika masyarakat yang akan datang.

Catatan penting dalam pengembangan kajian Islam di perguruan tinggi cenderung tidak adanya program yang berkesinambungan. Kerjasama dengan pelbagai pusat keunggulan akademik antarbangsa di masa lalu, kini tidak lagi dilakukan. Bahkan berhenti sama sekali. Begitu juga dengan keberadaan lembaga yang menjadi penaung perguruan tinggi di kementerian, justru secara parsial tidak menjadi mitra strategis. Bahkan memosisikan diri sebagai institusi perguruan tinggi.

Jikalau di UIN Sunan Ampel dalam satu fakultas, semua program studi mengelola jurnal nasional terakreditasi, berbeda dengan perguruan tinggi di Timur Indonesia. Hanya ada satu yaitu Jurnal Al-Ulum di IAIN Gorontalo. Padahal, terdapat 12 perguruan tinggi keagamaan Islam di wilayah timur mulai dari Makassar sampai ke Jayapura. Belum lagi fakultas agama Islam yang juga tersebar di wilayah yang sama. Disparitas ini kemudian perlu menjadi perhatian dimana semangat dalam pengelolaan terbitan berkala ilmiah belum menjadi perhatian yang sama di setiap lembaga.

Terakhir, ada ketimpangan antara satu kawasan dengan kawasan tertentu. Jika bisa dinyatakan kawasan itu adalah pulau, maka ketimpangan antara Pulau Jawa dan pulau lain terdapat disparitas. Terutama antara STAIN yang berada di Jawa dengan luar Jawa. Untuk itu, perencanaan program yang mengedepankan distingsi perlu dipetakan, sekaligus tidak menjadikan variable mahasiswa sebagai pilar. Ada satu masalah yang muncul jikalau hanya menggunakan mahasiswa sebagai bagian perencanaan. Kampus-kampus di minoritas muslim seperti di Sorong, Jayapura, dan Manado, tentu tidak akan mendapatkan input mahasiswa sebagaimana di wilayah mayoritas muslim. Dengan demikian, distingsi keilmuan akan menjadi komponen utama dalam pengembangan perguruan tinggi. 


\section{DAFTAR PUSTAKA}

Abdullah, M. Amin. Studi Agama Normativitas atau Historisitas?, Yogyakarta: Pustaka Pelajar, 1996.

Islamic Studies di Perguruan Tinggi Pendekatan Integratif-Interkonektif, Yogyakarta: Pustaka Pelajar, 2006. Religia, 2004.

Basuki., Dkk. Menakar Integrasi Interkoneksi Keilmuan, Ponorogo: STAIN Ponorogo, 2016.

Rahardjo, Mudjia. Quo V adis Pendidikan Islam, Malang: UIN-Malang Press, 2006.

Subhan, Zaitunah. Tafsir Kebencian, Yogyakarta: LKiS, 1999.

Umar, Nasaruddin. Argumen Kesetaraan Jender Perspektif Al-Qur'an, Jakarta: Penerbit Paramadina, 2001.

Wekke, Ismail Suardi. "Lembaga Pendidikan Sebagai Pilar Dakwah di Wilayah Minoritas Muslim." Jurnal Dakwah Albikmah, Volume 4, No. 2, 2013.

Wekke, Ismail Suardi., Dkk. "Keberagamaan Mahasiswa di Perguruan Tinggi Wilayah Minoritas Muslim." ULUL ALBAB Jurnal Studi Islam, Volume 17, No. 2, 2017.

Yorke, Mantz. "Formative assessment in higher education: Moves towards theory and the enhancement of pedagogic practice." Higher education, Volume 45 Number 4, 2003. 